\title{
Actinocorallia gen. nov., a New Genus of the Order Actinomycetales
}

\author{
SHIGEMI IINUMA, ${ }^{1}$ AKIRA YOKOTA, ${ }^{2}$ TORU HASEGAWA, ${ }^{2}$ AND TSUNEO KANAMARU ${ }^{1 *}$ \\ Discovery Research Laboratories II, Discovery Research Division, Takeda Chemical Industries, Ltd., ${ }^{1}$ \\ and Institute for Fermentation, Osaka, ${ }^{2}$ Juso-honmachi, Yodogawa-ku, Osaka 532, Japan
}

\begin{abstract}
One species of the new genus Actinocorallia, Actinocorallia herbida sp. nov., is described. The genus Actinocorallia is characterized by well-developed, branched, nonfragmented substrate mycelia. On the tips of unique coralloid sporophores, which arise from the substrate mycelia, long chains of nonmotile spores (more than 30 spores per chain) are borne. On rare occasions formation of coremia is observed. The chemotaxonomic characteristics of this organism are as follows: the cell wall chemotype is type III (meso-diaminopimelic acid), the whole-cell sugar pattern is type $C$ (no diagnostic sugar type), the fatty acid pattern is type 1a (straight-chain saturated acids and monounsaturated acids), the predominant isoprenoid quinones are MK-9 $\left(\mathrm{H}_{4}\right)$ and MK-9 $\left(\mathrm{H}_{6}\right)$, phospholipid type PII (phosphatidylethanolamine) is present as the diagnostic polar lipid, the $N$-acyl type of muramic acid in the cell wall is the acetyl type, and the guanine-plus-cytosine content of the DNA is 73 mol\%. The type strain of $A$. herbida is strain AL-50780 (= IFO 15485).
\end{abstract}

During the course of isolation of actinomycetes from soil in screening programs for pharmacologically active compounds, actinomycete strain AL-50780 ${ }^{\mathrm{T}}$ ( $\mathrm{T}=$ type strain), which had unusual morphological characteristics, was isolated from a soil sample collected in Bangkok, Thailand, and its taxonomic status was studied. This isolate formed unique coralloid sporophores on substrate mycelia and rarely formed coremia on solid media. Moreover, this isolate has the following novel chemotaxonomic characteristics: the cell wall type is type III (meso-2,6-diaminopimelic acid, meso-diaminopimelic acid, and no glycine), the whole-cell sugar pattern type is type $C$ (no diagnostic sugars), and the fatty acid type is type 1a. The genera that have type III/C cell walls are Brevibacterium, Geodermatophilus, Actinosynnema, Microtetraspora, Nocardiopsis, Saccharothrix, Streptoalloteichus, Thermomonospora, and Thermoactinomyces. However, the characteristics of these genera are not consistent with the strain AL- $50780^{\mathrm{T}}$ morphological or chemotaxonomic characteristics (5). The genera that have fatty acid type 1a are Actinomyces (cell wall types $\mathrm{V}$ and VI), Arcanobacterium (cell wall type VI), Dermatophilus (cell wall type III/B), Corynebacterium (cell wall type IV/A), and Intrasporangium (cell wall type I). The characteristics of these genera also are not consistent with strain AL-50780 ${ }^{\mathrm{T}}$ cell wall type and morphological characteristics (5).

We propose that strain AL-50780 ${ }^{\mathrm{T}}$ should be included in a new genus, Actinocorallia. Strain IFO 15485 (= AL-50780) is the type strain of the type species, Actinocorallia herbida.

In addition, this strain produces an azaserine-like antibiotic.

\section{MATERIALS AND METHODS}

Bacterial strain and culture conditions. Strain AL-50780 was isolated in 1992 from a soil sample from Bangkok, Thailand, by the dilution agar plating method, using colloidal chitin-vitamin agar containing (per liter) $1 \mathrm{~g}$ of chitin, $1.71 \mathrm{~g}$ of $\mathrm{KCl}, 1.63 \mathrm{~g}$ of $\mathrm{Na}_{2} \mathrm{HPO}_{4}, 18 \mathrm{~g}$ of agar, $20 \mathrm{mg}$ of $\mathrm{CaCO}_{3}, 10 \mathrm{mg}$ of $\mathrm{FeSO}_{4} \cdot 7 \mathrm{H}_{2} \mathrm{O}, 50 \mathrm{mg}$ of $\mathrm{MgSO}_{4} \cdot 7 \mathrm{H}_{2} \mathrm{O}, 1 \mathrm{mg}$ of thiamine$\mathrm{HCl}, 1 \mathrm{mg}$ of riboflavin, $1 \mathrm{mg}$ of niacin, $1 \mathrm{mg}$ of pyridoxine-

\footnotetext{
* Corresponding author. Mailing address: Discovery Research Laboratories, Takeda Chemical Industries, Ltd., Juso-honmachi-2, Yodogawa-ku, Osaka 532, Japan. Phone: 06-300-6415. Fax: 06-300-6276.
}

$\mathrm{HCl}, 1 \mathrm{mg}$ of inositol, $1 \mathrm{mg}$ of calcium pantothenate, $1 \mathrm{mg}$ of $p$-aminobenzoic acid, $0.5 \mathrm{mg}$ of biotin, $50 \mathrm{mg}$ of cycloheximide, and $10 \mathrm{mg}$ of kabicidin ( $\mathrm{pH} \mathrm{7.2).}$

In this study, the strain was grown on OMH agar containing $2.2 \%$ International Streptomyces Project (ISP) medium 3 (Difco), $0.1 \%$ yeast extract, $0.02 \%$ humic acid, and $1.5 \%$ agar or on yeast extract-malt extract agar (ISP medium 2) at $28^{\circ} \mathrm{C}$ for 10 days.

Morphological characteristics. For scanning electron microscopy, samples of 7- or 14-day colonial growth from cultures grown at $28^{\circ} \mathrm{C}$ on ISP medium 2, oatmeal agar (ISP medium 3), glycerol-asparagine agar (ISP medium 5), and HV agar (9) were prepared by cutting agar blocks from the growth media. The blocks were trimmed, dehydrated through a graded ethanol series, transferred to isoamyl acetate, and then critical point dried by using liquid carbon dioxide. Each specimen was sputter coated with gold-palladium and observed with a scanning electron microscope (model S-570; Hitachi Co., Ltd.).

Cultural and physiological characteristics. To determine cultural and physiological characteristics, we used the ISP media described by Shirling and Gottlieb (20) and the media described by Waksman (26). Cultures were incubated at $28^{\circ} \mathrm{C}$ and observed after 7 and 14 days. Culture color was determined by using color chips from the Color Harmony Manual (10). Carbohydrate utilization was determined by the method of Pridham and Gottlieb (18). The temperature range for growth was determined on ISP medium 2 with a model TN-3 temperature gradient incubator (Toyo Kagaku Sangyo Co., Ltd.) after 7 days. Levels of tolerance to sodium chloride, lysozyme, and antibiotics were determined by using ISP medium 2 as the basal medium. Gelatin liquefaction, starch hydrolysis, and reactions on milk were determined by the methods of Gordon et al. (6) and Goodfellow (4).

Chemical analyses of cell components. For chemotaxonomic analyses, freeze-dried cells were obtained from cultures grown in TYG medium containing $1 \%$ glucose, $1 \%$ tryptone, and $0.6 \%$ yeast extract $(\mathrm{pH} 7.0)$ on a rotary shaker at $28^{\circ} \mathrm{C}$ for 7 days. Cell walls were prepared by the method of Yamaguchi (27). Purified cell walls were hydrolyzed with $4 \mathrm{~N} \mathrm{HCl}$ at $100^{\circ} \mathrm{C}$ for $12 \mathrm{~h}$, and amino acid composition and isomers of diaminopimelic acid were determined with an amino acid analyzer (model 835; Hitachi Co., Ltd.) and by high-performance liquid chromatography (HPLC) (Hitachi Co., Ltd.) (22), respectively. 

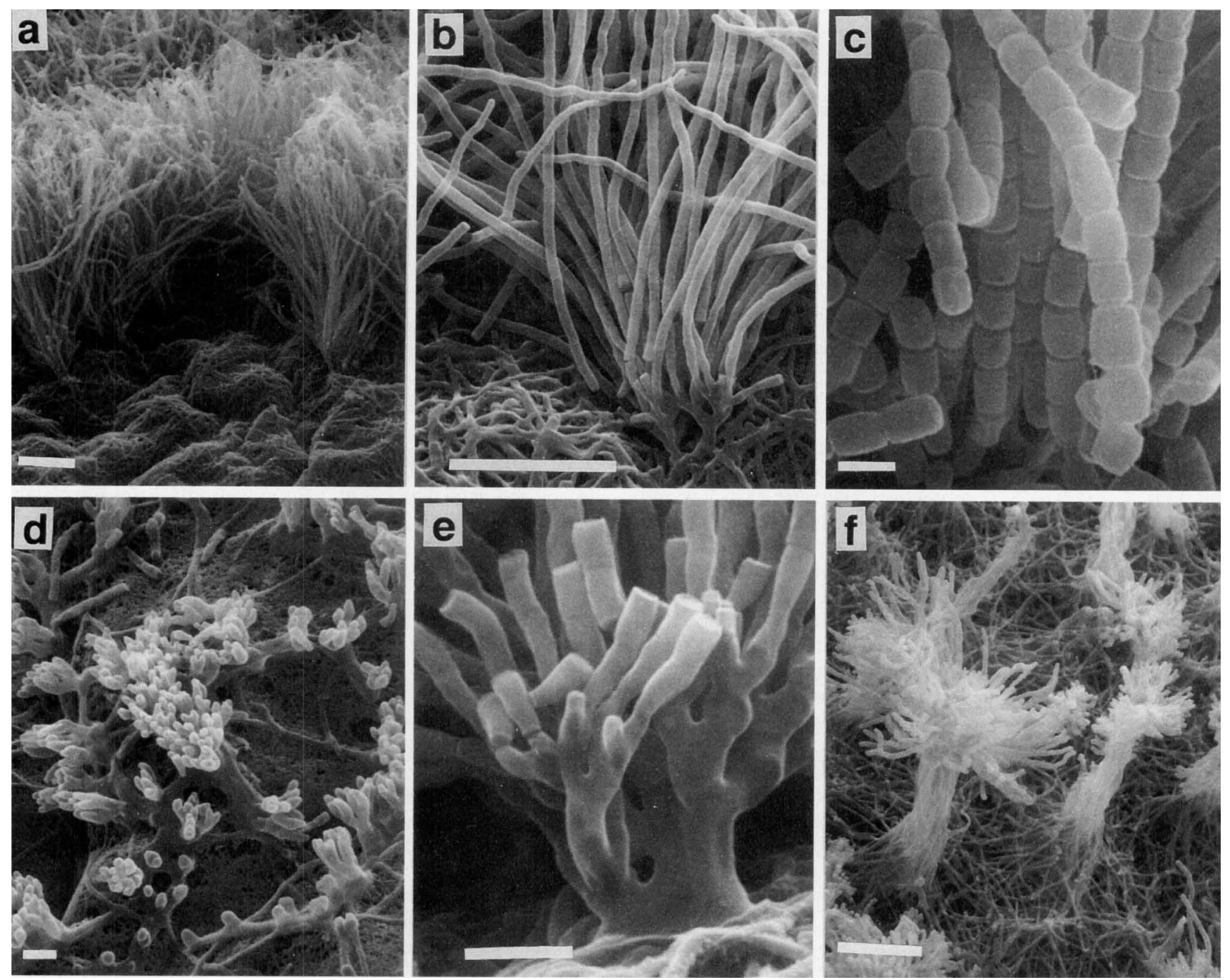

FIG. 1. Scanning electron micrographs of strain AL-50780 ${ }^{\mathrm{T}}$ grown on solid media for 14 days at $28^{\circ} \mathrm{C}$. (a and b) Aerial mycelia or spores on ISP medium 3. Bars $=10 \mu \mathrm{m}$. (c) Chains of spores on ISP medium 5. Bar $=1 \mu \mathrm{m}$. (d and e) Coralloid sporophores on HV agar and ISP medium 3. Bars $=2 \mu \mathrm{m}$. (f) Coremia on ISP medium 2. Bar $=5 \mu \mathrm{m}$.

The whole-cell sugar pattern was determined by hydrolyzing whole cells by the method of Hasegawa et al. (8) and also by the HPLC method of Mikami and Ishida (15). The fatty acid composition was determined by gas-liquid chromatography by using the method of Suzuki and Komagata (21). Isoprenoid quinones were extracted and purified by the method of Collins et al. (2) and were analyzed by HPLC by using the method of Tamaoka et al. (23). Phospholipid composition was determined by the method of Minnikin et al. (17). The $N$-acyl type of muramic acid in the cell wall was determined by the glycolate test of Uchida and Aida (25). The mycolic acid was determined by the method of Minnikin et al. (16).

DNA preparation and DNA base composition. DNA was extracted by the method of Saito and Miura (19). The guanineplus-cytosine $(G+C)$ content of DNA was determined by HPLC by using the method of Tamaoka and Komagata (24).

\section{RESULTS}

Morphological characteristics. Strain AL-50780 ${ }^{\mathrm{T}}$ exhibited unusual morphological features on ISP medium 2, ISP medium
3, ISP medium 5, and HV agar (Fig. 1); namely, strain AL-50780 ${ }^{\mathrm{T}}$ produced well-developed, branched, nonfragmented substrate mycelia. On the tips of unique coralloid sporophores that arose from the substrate mycelia (Fig. 1d and e), long chains of nonmotile spores (more than 30 spores per chain) were borne (Fig. 1a through c). On rare occasions coremia formation was observed on ISP medium 2 (Fig. 1f). Each spore was cylindrical $(0.7$ to 0.8 by 0.9 to $1.2 \mu \mathrm{m})$ and had a smooth surface (Fig. 1c). No sporangia, sclerotia, fragmentation of the substrate mycelia, or motile spores were observed.

Cultural and physiological characteristics. The cultural characteristics of strain AL-50780 ${ }^{\mathrm{T}}$ on various media are shown in Table 1. In general, growth of this strain was poor to moderate. The substrate mycelia were ivory to pale yellowish brown, and no distinct soluble pigments were produced. The aerial mycelia were white to pale yellow on several media (ISP medium 2, ISP medium 3, and ISP medium 5). The physiological characteristics of the strain are summarized in Table 2.

Chemotaxonomic characteristics. Hydrolysates of cell walls (in duplicate) of strain AL- $50780^{T}$ contained meso-diaminopimelic acid, as well as glycine, glutamic acid, and alanine. 
TABLE 1. Cultural characteristics of strain AL-50780 ${ }^{\mathrm{Ta}}$

\begin{tabular}{|c|c|c|c|c|}
\hline Medium & Growth & Aerial mycelium & Reverse color & Soluble pigment \\
\hline Sucrose-nitrate agar & Poor & Poor, white & Light ivory $(2 \mathrm{ca})$ & None \\
\hline Yeast extract-malt extract agar & $\begin{array}{l}\text { Moderate, butter yellow }(11 / 2 \mathrm{ga}) \text {, } \\
\text { coremia formed }\end{array}$ & Poor, white & Honey gold ( 2 ic) & None \\
\hline Oatmeal agar & Moderate & Moderate, squash yellow (2 ia) & Colonial yellow (2 ga) & None \\
\hline Inorganic salts-starch agar & Poor, light wheat ( 2 ea) & None & Light wheat ( 2 ea) & None \\
\hline Glycerol-asparagine agar & Poor & Poor, white & Light ivory $(2 \mathrm{ca})$ & None \\
\hline Glucose-asparagine agar & Poor, light ivory $(2 \mathrm{ca})$ & None & Light ivory (2 ca) & None \\
\hline Peptone-yeast extract-iron agar & $\begin{array}{l}\text { Poor to moderate, light wheat } \\
\text { ( } 2 \text { ea) }\end{array}$ & None & Light wheat ( 2 ea) & None \\
\hline Tyrosine agar & Poor & None & Light ivory (2 ca) & Dusty coral $(6 \mathrm{gc})$ \\
\hline Nutrient agar & $\begin{array}{l}\text { Poor to moderate, light wheat } \\
\text { ( } 2 \text { ea) }\end{array}$ & Poor, white & Light wheat ( 2 ea) & None \\
\hline
\end{tabular}

${ }^{a}$ See reference 10 for color designations.

The relative molar amounts of meso-diaminopimelic acid, glycine, glutamic acid, and alanine were 0.79 to $1.15,0.41$ to $0.60,1.00$, and 1.39 to 1.70 , respectively; because of its low and variable content, glycine was not considered to be a component of the backbone structure of the cell wall. Consequently, we concluded that the cell wall type was type III (14). The $N$-acyl type of muramic acid in the cell walls was determined to be the acetyl type. Ribose, mannose, galactose, and a large amount of glucose were detected in hydrolysates of whole cells, but arabinose, xylose, and madurose (3- $O$-methyl-D-galactose) were absent (whole-cell sugar pattern $\mathrm{C}$ of Lechevalier and Lechevalier [14]). The polar lipid profile was characterized by the presence of phosphatidylethanolamine and diphosphatidylglycerol and by the absence of phosphatidylcholine and unknown glucosamine-containing phospholipids, which suggests that the phospholipid pattern type is type PII of Lechevalier et

TABLE 2. Physiological characteristics of strain AL-50780 ${ }^{\mathrm{T}}$

\begin{tabular}{|c|c|}
\hline Characteristic & $\begin{array}{c}\text { Strain } \\
\text { AL-50780 }\end{array}$ \\
\hline 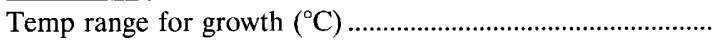 & $12-38$ \\
\hline Optimum temp range $\left({ }^{\circ} \mathrm{C}\right)$ & $24-32$ \\
\hline Reduction of nitrate & $-^{a}$ \\
\hline 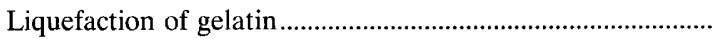 & - \\
\hline Hydrolysis of starch & + \\
\hline Coagulation of milk & - \\
\hline Peptonization of milk & - \\
\hline 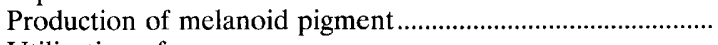 & - \\
\hline \multicolumn{2}{|l|}{ Utilization of: } \\
\hline L-Arabinose & - \\
\hline D-Xylose & - \\
\hline D-Glucose & + \\
\hline D-Fructose & + \\
\hline Sucrose & + \\
\hline myo-Inositol & - \\
\hline L-Rhamnose & + \\
\hline Raffinose & - \\
\hline 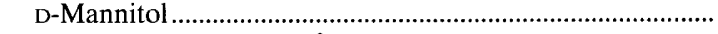 & - \\
\hline \multicolumn{2}{|l|}{ Growth in the presence of: } \\
\hline $\mathrm{NaCl}(3 \%, \mathrm{wt} / \mathrm{vol})$ & + \\
\hline $\mathrm{NaCl}(5 \%, \mathrm{wt} / \mathrm{vol})$ & - \\
\hline Lysozyme $(0.005 \%, \mathrm{wt} / \mathrm{vol})$ & + \\
\hline Cefsulodin $(100 \mu \mathrm{g} / \mathrm{ml})$ & + \\
\hline Gentamicin $(100 \mu \mathrm{g} / \mathrm{ml})$ & - \\
\hline Novobiocin $(20 \mu \mathrm{g} / \mathrm{ml})$ & - \\
\hline Rifampin $(50 \mu \mathrm{g} / \mathrm{ml})$ & - \\
\hline 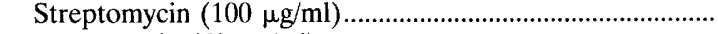 & - \\
\hline Vancomycin $(50 \mu \mathrm{g} / \mathrm{ml})$ & - \\
\hline
\end{tabular}

${ }^{a}+$, positive; - , negative. al. (13). MK-9( $\left.\mathrm{H}_{4}\right)$ and MK-9(Ho $\left.\mathrm{H}_{6}\right)$ were the predominant menaquinones, and a small amount of $\mathrm{MK}-9\left(\mathrm{H}_{8}\right)$ was detected in cell extracts. The cellular fatty acids consisted of straightchain saturated acids and monounsaturated acids (Table 3); this indicates that the fatty acid pattern type of strain AL$50780^{\mathrm{T}}$ is type $1 \mathrm{a}$ of Kroppenstedt (11). Cellular mycolic acids were not detected. The $\mathrm{G}+\mathrm{C}$ content of the DNA of strain AL- $50780^{\mathrm{T}}$ was $73 \mathrm{~mol} \%$.

\section{DISCUSSION}

Several genera of the order Actinomycetales are somewhat similar to the strain described above with regard to some morphological characteristics. However, strain AL-50780 ${ }^{\mathrm{T}}$ differs from them in many other morphological and chemotaxonomic features. A comparison of the morphological and chemotaxonomic characteristics of strain AL-50780 ${ }^{\mathrm{T}}$ with those of related genera is shown in Table $4(1,3,5,7,12)$. Members of the genera Catellatospora (1), Herbidospora (12), and "Sarraceniospora" (3) are similar to strain AL-50780" in that they form long chains of nonmotile spores from vegetative mycelia on the surfaces of agar media. However, members of the genus Catellatospora differ from our strain in cell wall chemotype, whole-cell sugar pattern, fatty acid pattern, and the $N$-acyl type of muramic acid. Members of the genus Herbidospora differ in whole-cell sugar pattern, fatty acid pattern, the type of major menaquinone, and phospholipid type, and members of the genus "Sarraceniospora" differ by producing sporangia in which long chains of nonmotile spores are covered by a membrane. Members of the genus Actinosynnema (7) are known to produce coremia on the surfaces of agar media. However, Actinosynnema strains differ from strain AL-50780 ${ }^{\mathrm{T}}$ in spore motility and fatty acid pattern.

Thus, strain AL-50780 $\mathrm{T}$ can be differentiated by its unique

TABLE 3. Cellular fatty acid composition of strain AL-50780 ${ }^{\mathrm{T}}$

\begin{tabular}{|c|c|}
\hline Fatty acid & $\begin{array}{l}\text { Peak } \\
\text { area }(\%)\end{array}$ \\
\hline \multicolumn{2}{|l|}{ Straight-chain saturated acids } \\
\hline 15:0 & 4.3 \\
\hline 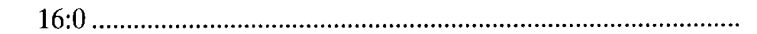 & 25.8 \\
\hline 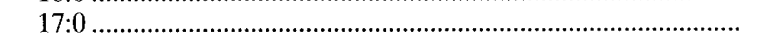 & 8.3 \\
\hline 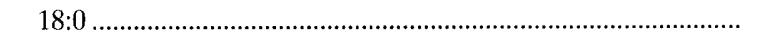 & 3.8 \\
\hline \multicolumn{2}{|l|}{ Straight-chain monounsaturated acids } \\
\hline $16: 1$ & 15.4 \\
\hline $17: 1$ & 16.0 \\
\hline $18: 1$ & 26.5 \\
\hline
\end{tabular}


TABLE 4. Differential characteristics for strain AL-50780 $0^{\mathrm{T}}$ and related actinomycete genera ${ }^{a}$

\begin{tabular}{|c|c|c|c|c|c|c|c|c|c|c|}
\hline Taxon & $\begin{array}{c}\text { Aerial } \\
\text { mycelium }\end{array}$ & $\begin{array}{c}\text { Spore } \\
\text { arrangement }\end{array}$ & $\begin{array}{l}\text { Spore } \\
\text { motility }\end{array}$ & $\begin{array}{l}\text { Cell wall } \\
\text { chemotype }\end{array}$ & $\begin{array}{l}\text { Whole-cell } \\
\text { sugar } \\
\text { pattern }\end{array}$ & $\begin{array}{c}\text { Fatty } \\
\text { acid } \\
\text { pattern }\end{array}$ & $\begin{array}{c}\text { Major } \\
\text { menaquinone(s) }\end{array}$ & $\begin{array}{l}\text { Phospholipid } \\
\text { type }\end{array}$ & $\begin{array}{c}\text { Muramic } \\
\text { acid acyl } \\
\text { type }\end{array}$ & $\begin{array}{c}\mathrm{G}+\mathrm{C} \text { content } \\
\text { of DNA } \\
(\mathrm{mol} \%)\end{array}$ \\
\hline AL- $50780^{\mathrm{T}}$ & Present & Chains & - & III & $\mathrm{C}$ & $1 \mathrm{a}$ & MK-9 $\left(\mathrm{H}_{4}, \mathrm{H}_{6}\right)$ & PII & Acetyl & 73 \\
\hline Catellatospora & Absent & Chains & - & II & $\mathrm{D}$ & $2 \mathrm{~b}^{b}$ & $\begin{array}{c}\text { MK-9( }\left(\mathrm{H}_{4}, \mathrm{H}_{6}\right) \text { or MK- } \\
10\left(\mathrm{H}_{6}, \mathrm{H}_{8}\right)\end{array}$ & PII & Glycolyl & $71-72$ \\
\hline "Sarraceniospora" & Present & $\begin{array}{l}\text { Chains in } \\
\text { sporangia }\end{array}$ & - & II & $\mathrm{D}$ & $2 a^{b}$ & $\mathrm{MK}-9\left(\mathrm{H}_{6}, \mathbf{H}_{8}\right)$ & PII & Glycolyl & $70-72$ \\
\hline Herbidospora & Absent & Chains & - & III & B & $3 c$ & $\begin{array}{l}\left.\text { MK-10(III, IX-H }{ }_{4}\right) \\
\text { MK-10 }\left(\mathrm{H}_{2}, \mathrm{H}_{6}\right)\end{array}$ & PIV & Acetyl & $69-71$ \\
\hline Actinosynnema & Present & Chains & + & III & $\mathrm{C}$ & $3 \mathrm{f}$ & MK-9 $\left(\mathrm{H}_{4}\right), \mathrm{MK}-10\left(\mathrm{H}_{4}\right)$ & PII & Acetyl & $71-73$ \\
\hline
\end{tabular}

"Data from references $1,3,5,7$, and 12 .

${ }^{b}$ Data from this study.

morphological and chemotaxonomic characteristics; this finding supports our conclusion that strain AL-50780 ${ }^{\mathrm{T}}$ does not belong to any previously described genus (Table 4).

Consequently, we propose the creation of a new genus, Actinocorallia, to accommodate this strain. Actinocorallia herbida IFO 15485 is the type strain of the type species.

Description of Actinocorallia gen. nov. Actinocorallia (Ac.ti. no.co.ral' li.a. Gr. n. actis, a ray; Gr. n. corallium, coral; Gr. n. Actinocorallia, referring to a microorganism that forms sporophores resembling coral). Gram positive and aerobic. Vegetative mycelia are branched but not fragmented. Sporophores arise from substrate mycelia, and on the tips of the sporophores long chains of nonmotile spores are formed (Fig. 1b and c). Type III cell wall composition (meso-2,6-diaminopimelic acid). The whole-cell sugar pattern type is type $C$ (no diagnostic sugars). Mycolic acid is absent. Type 1a fatty acid pattern (straight-chain saturated acids and monounsaturated acids). The predominant menaquinones are $\mathrm{MK}-9\left(\mathrm{H}_{4}\right)$ and MK-9 $\left(\mathrm{H}_{6}\right)$. Type PII phospholipid pattern (phosphatidylethanolamine, no phosphatidylcholine, no glucosamine-containing phospholipids). The $N$-acyl type of the muramic acid is acetyl. The type species is Actinocorallia herbida.

Description of Actinocorallia herbida sp. nov. Actinocorallia herbida (her'bi.da. L. adj. herbidus, grassy, referring to the formation of aerial mycelia like grass). The substrate mycelium is ivory to pale yellowish brown; the aerial mycelium is white to pale yellow. Soluble pigment is not produced. Starch is hydrolyzed. Nitrate is not reduced. Gelatin is not liquefied. Milk is not coagulated or peptonized. Utilizes D-glucose, D-fructose, sucrose, and L-rhamnose but not L-arabinose, D-xylose, inositol, raffinose, or D-mannitol. Growth occurs in the presence of $3 \% \mathrm{NaCl}$ but not in the presence of $5 \% \mathrm{NaCl}$. Resistant to lysozyme and cefsulodin but not to gentamicin, novobiocin, rifampin, streptomycin, or vancomycin. The temperature range for growth is 12 to $38^{\circ} \mathrm{C}$, and the optimum growth temperature range is 24 to $32^{\circ} \mathrm{C}$. The $\mathrm{G}+\mathrm{C}$ content of the DNA is $73 \mathrm{~mol} \%$. The type strain is strain IFO 15485 (= AL-50780).

\section{ACKNOWLEDGMENTS}

We thank Hisayoshi Okazaki for his encouragement throughout this study. We also thank Werasit Kanlayakrit, Department of Biotechnology, Kasetsart University, Bangkok, Thailand, for his cooperation. The technical assistance of Yasuharu Yamamoto and Akira Tokuhara is gratefully acknowledged.

\section{REFERENCES}

1. Asano, K., and I. Kawamoto. 1986. Catellatospora, a new genus of the Actinomycetales. Int. J. Syst. Bacteriol. 36:512-517.

2. Collins, M. D., T. Pirouz, M. Goodfellow, and D. E. Minnikin.
1977. Distribution of menaquinones in actinomycetes and corynebacteria. J. Gen. Microbiol. 100:221-230.

3. Furihata, K., K. Ikeda, A. Shimazu, and H. Seto. 1989. Sarraceniospora, a new genus of the Actinomycetales, p. 9-12. In Y. Koyama (ed.), Trends in actinomycetology in Japan. Society for Actinomycetes, Tokyo, Japan.

4. Goodfellow, M. 1971. Numerical taxonomy of some nocardioform bacteria. J. Gen. Microbiol. 69:33-80.

5. Goodfellow, M. 1989. The actinomycetes. I. Suprageneric classification of actinomycetes, p. 2333-2339. In S. T. Williams, M. E. Sharpe, and J. G. Holt (ed.), Bergey's manual of systematic bacteriology, vol. 4. Williams \& Wilkins, Baltimore.

6. Gordon, R. E., D. A. Barnett, J. E. Handerhan, and C. H.-N. Pang. 1974. Nocardia coeliaca, Nocardia autotrophica, and the nocardin strain. Int. J. Syst. Bacteriol. 24:54-63.

7. Hasegawa, T., M. P. Lechevalier, and H. A. Lechevalier. 1978. New genus of the Actinomycetales: Actinosynnema gen. nov. Int. J. Syst. Bacteriol. 28:304-310.

8. Hasegawa, T., M. Takizawa, and S. Tanida. 1983. A rapid analysis for chemical grouping of aerobic actinomycetes. J. Gen. Appl. Microbiol. 29:319-322.

9. Hayakawa, M., and H. Nonomura. 1987. Humic acid-vitamin agar, a new medium for the selective isolation of soil actinomycetes. $\mathbf{J}$. Ferment. Technol. 65:501-509.

10. Jacobson, E., W. C. Grauville, and C. E. Fogs. 1958. Color harmony manual, 4th ed. Container Corporation of America, Chicago.

11. Kroppenstedt, R. M. 1985. Fatty acid and menaquinone analysis of actinomycetes and related organisms, p. 173-199. In M. Goodfellow and D. E. Minnikin (ed.), Chemical methods in bacterial systematics. Academic Press, Ltd., London.

12. Kudo, T., T. Itoh, S. Miyadoh, T. Shomura, and A. Seino. 1993. Herbidospora gen. nov., a new genus of the family Streptosporangiaceae Goodfellow et al. 1990. Int. J. Syst. Bacteriol. 43:319-328.

13. Lechevalier, M. P., C. De Bievre, and H. A. Lechevalier. 1977. Chemotaxonomy of aerobic actinomycetes: phospholipid composition. Biochem. Syst. Ecol. 5:249-260.

14. Lechevalier, M. P., and H. A. Lechevalier. 1970. Chemical composition as a criterion in the classification of aerobic actinomycetes. Int. J. Syst. Bacteriol. 20:435-443.

15. Mikami, H., and Y. Ishida. 1983. Post-column fluorometric detection of reducing sugars in high performance liquid chromatography using arginine. Bunseki Kagaku 32:E207-E210.

16. Minnikin, D. E., L. Alshamaony, and M. Goodfellow. 1975. Differentiation of Mycobacterium, Nocardia, and related taxa by thin-layer chromatographic analysis of whole-organism methanolysates. J. Gen. Microbiol. 88:200-204.

17. Minnikin, D. E., A. G. O'Donnell, M. Goodfellow, G. Alderson, M. Athalye, A. Schaal, and J. H. Parlett. 1984. An integrated procedure for the extraction of bacterial isoprenoid quinones and polar lipids. J. Microbiol. Methods 2:233-241.

18. Pridham, T. G., and G. Gottlieb. 1948. The utilization of carbon compounds by some Actinomycetales as an aid for species determination. J. Bacteriol. 56:107-114.

19. Saito, H., and K. Miura. 1963. Preparation of transforming 
deoxyribonucleic acid by phenol treatment. Biochim. Biophys. Acta 72:619-629.

20. Shirling, E. B., and D. Gottlieb. 1966. Methods for characterization of Streptomyces species. Int. J. Syst. Bacteriol. 16:313-340.

21. Suzuki, K., and K. Komagata. 1983. Taxonomic significance of cellular fatty acid composition in some coryneform bacteria. Int. J. Syst. Bacteriol. 33:188-200.

22. Takahashi, Y., Y. Iwai, H. Tomoda, N. Nimura, T. Kinoshita, and

S. Omura. 1989. Optical resolution of 2,6-diaminopimelic acid stereoisomers by high performance liquid chromatography for the chemotaxonomy of actinomycete strains. J. Gen. Appl. Microbiol. 35:27-32.

23. Tamaoka, J., Y. Katayama-Fujimura, and H. Kuraishi. 1983.
Analysis of bacterial menaquinone mixtures by high performance liquid chromatography. J. Appl. Bacteriol. 54:31-36.

24. Tamaoka, J., and K. Komagata. 1984. Determination of DNA base composition by reversed-phase high-performance liquid chromatography. FEMS Microbiol. Lett. 25:125-128.

25. Uchida, K., and K. Aida. 1984. An improved method for the glycolate test for simple identification of the acyl type of bacterial cell walls. J. Gen. Appl. Microbiol. 30:131-134.

26. Waksman, S. A. 1961. The actinomycetes, vol. 2. The Williams \& Wilkins Co., Baltimore.

27. Yamaguchi, T. 1965. Comparison of the cell-wall composition of morphologically distinct actinomycetes. J. Bacteriol. 89:444453. 